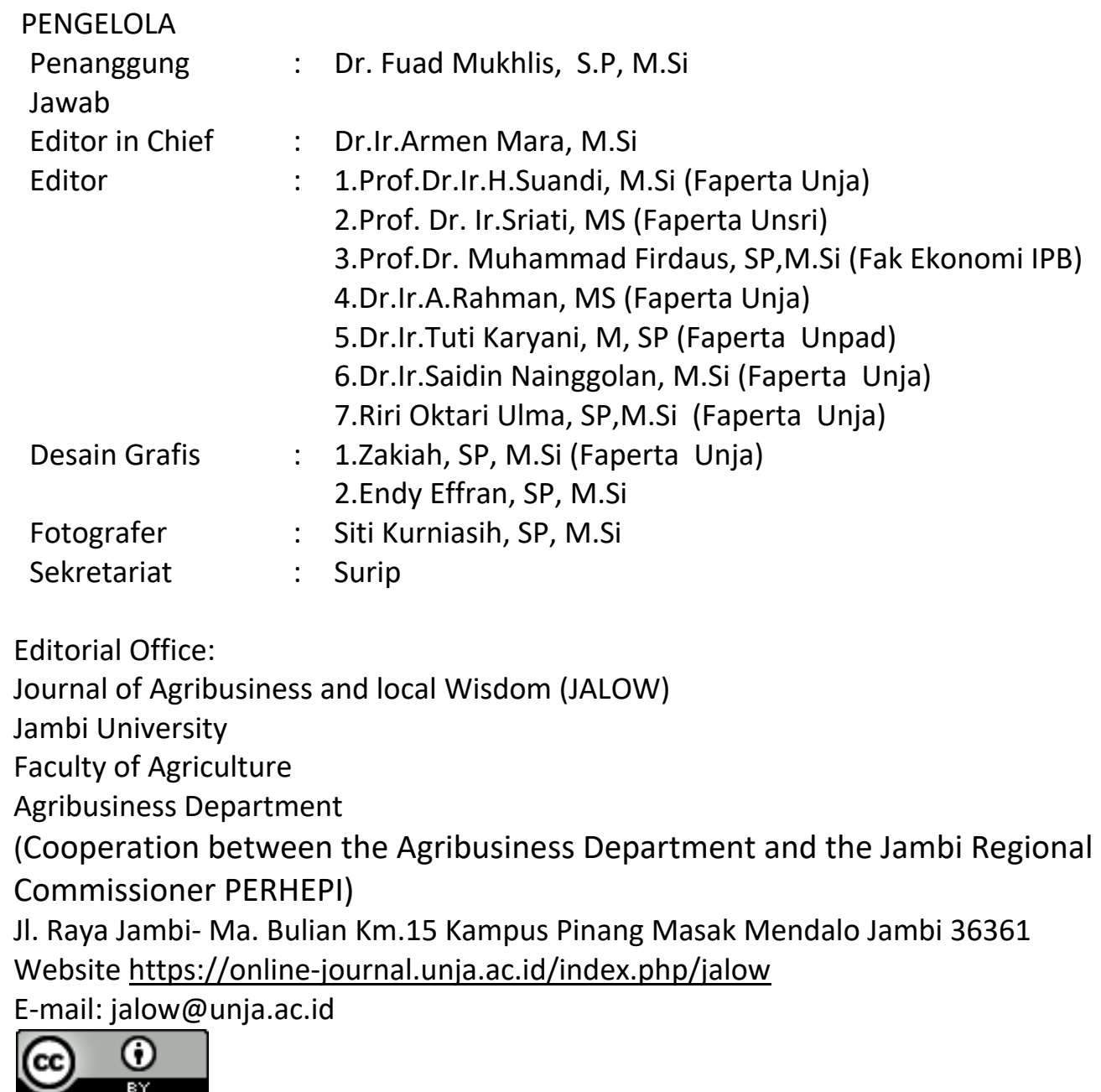

This work is licensed under a Creative Commons Attribution 4.0 International License. 


\section{Assalamualaikum wbwb}

\section{PENGANTAR}

Kondisi agribisnis tahun 2020 ini agak berbeda dengan tahun sebelumnya. Kebijakan penanggulangan Covid19 seperti "dirumah Aja, lockdown lokasi, Isolasi Mandiri, PSBB (Pembatasan Sosial Berskala Besar), dan Herd Immunity" telah merubah pola aktivitas masyarakat, khususnya di Kota-kota. Sebelumnya, berkejar2an dengan waktu untuk meningkatkan pendapatan dengan jalan menambah produktivitas dan menekan biaya telah dikagetkan oleh adanya ancaman pandemi Covid19 yang ada dimana-mana, semangat berkejar-kejaran tersebut kendur seketika.

Kegiatan perdagangan di Kota-kota besar maupun kota kecil telah mengalami kelesuan untuk semua lapisan, mulai dari pedagang kecil mikro, pedagang asongan atau gerobak, pedagang toko, mini market sampai perdagangan berskala besar, super market, dan mallmall. Hal ini menyebabkan terjadinya pengangguran, berkurangnya pendapatan masyarakat dan menurun drastisnya penerimaan pemerintah dari pajak. Selama masa isolasi, para konsumen melakukan belanja dengan sangat hati-hati. Pihak produsen merasakan berkurangnya permintaan. Oleh karena itu, walaupun kebijakan Covid19 tidak menghambat aktivitas produksi pertanian di lahan secara langsung namun karena permintaan berkurang maka berkurang pula pendapatan petani yang mengusahakan kebun atau sawah.

Kebiasaan konsumen yang selama ini lebih banyak makan di luar rumah berubah menjadi lebih banyak makan di rumah sendiri, masak sendiri atau pesan antar. Berbelanja yang semula mencari tempat2 yang banyak di kerumuni orang berubah ke tempat yang tidak ada kerumunannya, artinya rasa enak dan harga murah tidak lagi menjadi patokan utama bagi konsumen. Mereka lebih mengutamakan sehat dan terjamin dalam proses pembuatannya. Kesadaran adanya ancaman bahaya serangan Covid19 terhadap nyawa setiap orang telah menyebabkan berubah nya psikologi dan sosial masyarakat. Sebelumnya berpikir materialis dan untung rugi dari setiap kerja, sekarang mulai nampak adanya kepedulian terhadap perintah agama melaksanakan sholat dan bersedekah. Mulai terlihat adanya aktivitas sosial di tengah-tengah kota, ada kegiatan membagikan nasi bungkus kepada kaum duafah dan lapisan bawah, kegiatan membagikan sembako, membagikan ampelop berisi uang kertas, sampai pada aktivitas memberikan tip berupa uang dalam setiap kali berbelanja di pedagang-pedagang kecil.

Harapan untuk semua aktivitas-aktivitas positif tersebut berlangsung tidak sementara tapi menjadi karakter bagi setiap orang. Kalau aktivitas sosial ini terus dipertahankan oleh pelaku yang telah memulai nya tentu akan diikuti juga oleh yang lainnya. Diharapkan juga setiap pelaku agribisnis berskala kecil, baik yang disektor produksi pertanian maupun sektor industri pengolahan dan perdagangan dapat mengantisipasi perubahan prilaku konsumen tersebut dengan perubahan pola produksi yang sesuai sehingga peluang bisnis yang terlepas dari pola sebelumnya dapat ditangkap.

Demikian semoga JALOW untuk penerbitan ini bermanfaat untuk kita semua aamiin ya robbal aalamiin.

Waalaikumsalam wbwb

Editor in Chief

Dr.Ir.Armen Mara,M.Si 
DAFTAR ISI

\begin{tabular}{|c|c|}
\hline 1 & $\begin{array}{l}\text { ANALISIS RESPON PENAWARAN KOMODITI KEDELAI } \\
\text { DI KABUPATEN TANJAB TIMUR } \\
\text { Oleh Edison }\end{array}$ \\
\hline 2 & 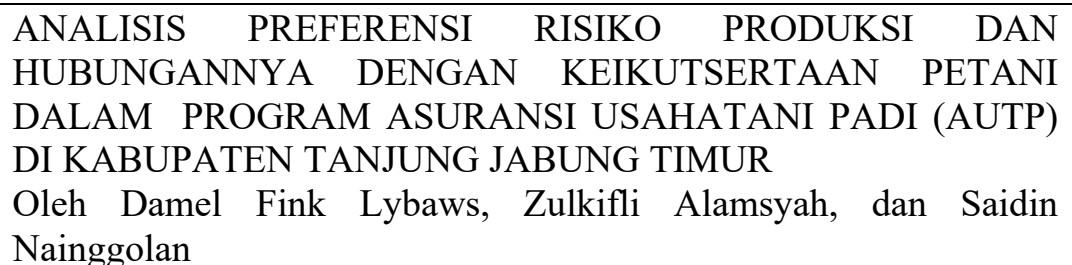 \\
\hline 3 & $\begin{array}{l}\text { ANALISIS USAHA IKAN HIAS AIR TAWAR DI KOTA JAMBI (ANALYSIS } \\
\text { OF FRESH WATER ORNAMENTAL FISH IN JAMBI CITY) } \\
\text { Dody Hadisaputra, Ernawati, Suandi }\end{array}$ \\
\hline 4 & $\begin{array}{l}\text { ANALISIS FAKTOR-FAKTOR YANG MEMPENGARUHI PRODUKSI } \\
\text { BOKAR (BAHAN OLAH KARET) DI KABUPATEN BATANGHARI } \\
\text { Oleh Elisabeth Lumban Gaol, Armen Mara, dan Riri Oktari UIma }\end{array}$ \\
\hline 5 & $\begin{array}{l}\text { ANALISIS PENGAMBILAN KEPUTUSAN UNTUK PEMBELIAN } \\
\text { MAKANAN KEMASAN BERLOGO HALAL MUI (STUDI KASUS IBU } \\
\text { RUMAH TANGGA DI PERUMAHAN AUR DURI DAN PERUMNAS KOTA } \\
\text { BARU, KOTA JAMBI) } \\
\text { Oleh Putri Hana Jusia, Saad Murdy, Lavlinesia }\end{array}$ \\
\hline 6 & \begin{tabular}{lcccc} 
STRATEGI & ADAPTASI & PETANI & DALAM & \multicolumn{2}{c}{ MENGHADAPI } \\
RENDAHNYA & HARGA & JUAL & KELAPA & SAWIT \\
KECAMATAN & SUNGAI & BAHAR & KABUPATEN & MUARO \\
JAMBI & & & \\
Oleh Fiona Andini ${ }^{1}$ ), Fuad Muchlis $^{2}$ ), Aulia Farida 2) & \\
\end{tabular} \\
\hline 7 & \begin{tabular}{lcllr}
\multicolumn{2}{l}{ KOLABORASI } & DALAM & PENGELOLAAN & \multicolumn{2}{c}{ PERKEBUNAN } \\
KELAPA SAWIT & RAKYAT & (STUDI KASUS: KUD & LUBUK \\
KARYA DAN & KUD & KAMPUNG & SURAU & KAB. \\
DHARMASRAYA & & & & \\
Oleh Yulistriani & & & & \\
\end{tabular} \\
\hline 8 & $\begin{array}{l}\text { KEPUTUSAN PETANI SAWIT DALAM MENGKONVERSI } \\
\text { LAHAN KELAPA SAWIT MENJADI LAHAN PADI SAWAH DI } \\
\text { KECAMATAN BATANG ASAM KABUPATEN } \\
\text { TANJUNG JABUNG BARAT } \\
\text { Oleh Krielson Ompusunggu1), Arsyad Lubis2, Siti Kurniasih2 }\end{array}$ \\
\hline 9 & $\begin{array}{l}\text { KAITAN BIAYA DAN TEKNIK PEREMAJAAN } \\
\text { KELAPA SAWIT RAKYAT } \\
\text { Oleh Nur Imdah Minsyah }\end{array}$ \\
\hline 10 & $\begin{array}{l}\text { STRATEGI RANTAI PASOK KELAPA SAWIT DI PROVINSI } \\
\text { SUMATERA BARAT } \\
\text { Oleh Rahma Dzulqa1*), Rika Ampuh Hadiguna2) }\end{array}$ \\
\hline
\end{tabular}




\title{
ANALISIS USAHA IKAN HIAS AIR TAWAR DI KOTA JAMBI
}

\author{
Analysis Of Fresh Water Ornamental Fish In Jambi City
}

\author{
Dody Hadisaputra ${ }^{1)}$ Ernawati $^{2)}$ Suandi $^{2)}$ \\ ${ }^{1)}$ Mahasiswa Program Studi Agribisnis Program Pascasarjana Universitas Jambi, \\ ${ }^{2)}$ Dosen Program Studi Agribisnis Program Pascasarjana Universitas Jambi, Indonesia \\ email: dodyjumpbee@gmail.com
}

\begin{abstract}
Ornamental fish is a fish that has a distinctive shape, color and character so as to create an aquarium atmosphere that supports spatial layout and is able to provide a peaceful atmosphere. The purpose of this study was to determine the description of ornamental fish business and analyze the feasibility of ornamental fish business in Jambi City. The qualitative method is used to describe descriptively the general description of the location of the study and the characteristics of ornamental fish farmers, while the quantitative method uses the Analysis of Income and Revenue of ornamental fish business, cost analysis, income analysis and cost balance (R/C Ratio), Net Benefits - Cost Ratios (Net $B / C)$, and institutionally descriptive for the betta fish, guppy and botia ornamental fish business. Overall, the general description of ornamental fish farming business in Jambi City is conducted conventionally. The average $R / C$ ratio of the Betta ornamental fish business is 2.60, guppy is 2.02 and botia is 1.22. The highest average NPV in the betta ornamental fish in the mid-scale farming business is Rp. 60,745,160.71, guppy on a large scale is $R p .31,385,065.48$, and botia on a large scale with a value of Rp. 78,034,144.35. Overall, this ornamental fish business has an NPV value of $>0$. The ornamental fish business in Jambi City is feasible to run and develop, betta ornamental fish business on a small scale with an average $B / C$ Ratio of 1.15 and medium with an average value of average 1.60, guppy on a small scale with an average value of 1.02 , and botia on a medium scale with an average value of 1.00 and large with a value of an average of 1.22. Keywords: Ornamental Fish, Jambi City.
\end{abstract}

\section{PENDAHULUAN}

Potensi perikanan di Kota Jambi akan mengalami penurunan setiap tahun dikarenakan pengembangan pembangunan di perkotaan yang lebih mengutamakan pembangunan di sektor jasa, perumahan, dan lainnya. Untuk itu diperlukan suatu regulasi yang tepat dalam pembangunan sektor perikanan di lahan perkotaan oleh Pemerintah Kota Jambi agar mampu menggerakkan perekonomian masyarakatnya melalui kebijakan pengembangan agribisnis perkotaan di Kota Jambidengan kondisi kepemilikan lahan yang sempit, mobilitas penduduk kota yang sangat tinggi, disamping posisi Kota Jambi yang strategis bila ditinjau dari sudut pasar. Berdasarkan data Badan Pusat Statistik (BPS) Kota Jambi tahun 2017, banyaknya ikan hias secara umum yang dipasarkan dan nilai produksinya menunnjukkan peningkatan, volume perdagangan ikan hias alam maupun budidaya dari Kota Jambi ke Provinsi atau negara tetangga, ini dapat dilihat pada Tabel 1. Tabel 1. Banyaknya Ikan Hias yang Di Pasarkan dan Nilai Produksinya Tahun 2006 - 2016. 


\begin{tabular}{ccrcr}
\hline Tahun & $\begin{array}{c}\text { Interinsuler } \\
\text { (ekor) }\end{array}$ & $\begin{array}{c}\text { Ekspor } \\
\text { (ekor) }\end{array}$ & $\begin{array}{c}\text { Jumlah Total } \\
\text { (ekor) }\end{array}$ & $\begin{array}{c}\text { Nilai } \\
\text { (Rp.000) }\end{array}$ \\
\hline 2006 & 560.500 & 280.045 & 840.545 & 210.136 \\
2007 & 280.500 & 50.000 & 330.500 & 85.625 \\
2008 & 315.000 & 85.000 & 400.000 & 110.000 \\
2009 & 790.000 & 75.000 & 865.000 & 259.500 \\
2010 & 2.462 .453 & 646.640 & 3.109 .093 & 1.933 .899 \\
2011 & 3.719 .884 & 619.610 & 4.339 .498 & 2.690 .488 \\
2012 & 2.979 .402 & 3.550 & 2.982 .952 & 1.893 .755 \\
2013 & 2.413 .268 & 1.457 .965 & 3.871 .233 & 5.806 .849 \\
2014 & 2.023 .118 & 462.887 & 2.486 .005 & 3.853 .307 \\
2015 & 1.597 .080 & 149.105 & 1.746 .185 & 8.186 .107 \\
2016 & 74.062 & 32.660 & 106.722 & 4.023 .727 \\
\hline
\end{tabular}

Sumber : Kota Jambi Dalam Angka 2017.

Perdagangan interinsuler (perdagangan antar pulau) ikan hias dari kota Jambi keluar Provinsi Jambi terlihat lebih tinggi dari pada perdagangan ekspor dikarenakan tidak membutuhkan izin yang terlalu sulit dan dapat dilakukan langsung oleh pembudidaya ikan hias, sedangkan perdagangan ekspor langsung dari Kota Jambi baru dilakukan oleh beberapa pedagang yang telah memiliki ijin ekspor dan perdagangan ekspor membutuhkan waktu cukup lama untuk sampai ke daerah tujuan di karenakan barang harus melalui proses transit di pusat cargo.

Jumlah Rumah Tangga Perikanan (RTP) ikan hias di Kota Jambi tahun 2016, tercatat sebanyak 103 orang seperti yang terlihat pada Tabel 2. Rumah Tangga Perikanan (RTP) ikan hias diprediksi akan terus meningkat dikarenakan usaha ini tidak membutuhkan lahan dan modal awal yang besar, sehingga akan lebih menambah minat masyarakat..

Tabel 2. Jumlah Rumah Tangga Perikanan (RTP) di Kota Jambi Tahun 2016.

\begin{tabular}{clrrrrrrr}
\hline No & Kecamatan & Kolam & KJA & UPR & $\begin{array}{c}\text { UPR } \\
\text { Pendeder }\end{array}$ & $\begin{array}{c}\text { Ikan } \\
\text { Hias }\end{array}$ & $\begin{array}{c}\text { Nelay } \\
\text { an }\end{array}$ & Jumlah \\
\hline 1. & Telanaipura & 63 & 413 & 24 & 8 & 12 & 204 & 724 \\
2. & Kota Baru & 427 & - & 7 & 8 & 8 & - & 450 \\
3. & Jelutung & 42 & - & 5 & 5 & 5 & - & 57 \\
4. & Pasar Jambi & - & - & - & - & - & - & - \\
5. & Jambi Selatan & 149 & - & 9 & 5 & 5 & - & 446 \\
6. & Jambi Timur & 138 & - & 2 & 10 & 18 & 64 & 242 \\
7. & Pelayangan & 9 & 53 & 5 & 6 & 25 & 206 & 304 \\
8. & Danau Teluk & 82 & 117 & 32 & 53 & 26 & 282 & 592 \\
9. & Danau Sipin & - & - & 4 & - & 2 & - & 6 \\
10. & Paal Merah & 288 & - & 4 & - & 2 & - & 6 \\
11. & Alam Barajo & - & - & - & - & - & - & - \\
\hline & Jumlah & 1.198 & 583 & 92 & 95 & 103 & 756 & 2.827 \\
\hline
\end{tabular}

Sumber : Laporan Tahunan Bidang Perikanan Tahun 2016.

Produksi ikan hias mengalami pergerakan produksi yang tidak stabil, hal ini dikarenakan usaha perikanan sangat bergantung terhadap kondisi alam dan iklim di tahun tersebut. Perkembangan produksi ikan hias di Kota Jambi ini dapat dilihat pada Tabel 3. 
Tabel 3. Produksi Ikan Hias di Kota Jambi Dari Tahun 2010 - 2016.

\begin{tabular}{|c|c|c|c|c|c|c|c|}
\hline $\begin{array}{l}\text { Kegiatan } \\
\text { Produksi }\end{array}$ & 2010 & 2011 & 2012 & 2013 & 2014 & 2015 & 2016 \\
\hline $\begin{array}{l}\text { - Ikan hias } \\
\text { Budidaya }\end{array}$ & 820.000 & 865.898 & 485.805 & 57.215 & 131.531 & 102.750 & 148.093 \\
\hline $\begin{array}{l}\text { - ikan hias } \\
\text { Tangkap } \\
\text { an } \\
\text { Alam }\end{array}$ & 874.000 & 1.079 .276 & 2.445 .700 & $\begin{array}{r}3.595 .27 \\
5\end{array}$ & $\begin{array}{r}1.777 .91 \\
4\end{array}$ & 1.589 .596 & 1.774 .374 \\
\hline Jumlah & 1.694 .000 & $\begin{array}{r}1.945 .17 \\
4\end{array}$ & 2.921.505 & $\begin{array}{r}3.652 .49 \\
0\end{array}$ & $\begin{array}{r}1.909 .44 \\
5\end{array}$ & 1.692 .346 & 1.922 .467 \\
\hline
\end{tabular}

Sumber : Data Diolah dari Laporan Statistik Dinas Pertanian Peternakan Perikanan dan Kehutanan Kota Jambi Bidang Perikanan.

Dari tabel 3. Diatas menunjukkan bahwa dari tahun 2010 hingga tahun 2016, produksi ikan hias hasil tangkapan masih menjadi produksi tertinggi di kota Jambi, namun jika dibandingkan dengan tahun sebelumnya terlihat terus menurun, hal ini lebih banyak dipengaruhi oleh faktor lingkungan perairan yang kurang baik, larva ikan hias hasil tangkapan di perairan umum di Kota Jambi tidak serta merta langsung dijual kepada konsumen akhir atau penikmat ikan hias, namun tetap diperlukan perawatan dan perlakuan budidaya terlebih dahulu selama $1-2$ bulan, hal ini dilakukan untuk membiasakan ikan dengan kondisi perairan yang baru dan di besarkan hingga mencapai ukuran yang diperbolehkan untuk diperdagangkan secara umum.

Pada sektor perikanan khususnya ikan hias diharapkan mampu memiliki peran besar pada perekonomian Kota Jambi dan memberikan dampak pengembangan yang baik terhadap perubahan struktur perekonomian Kota Jambi dan saat ini ada 103 RTP yang telah menjalankan usaha ikan hias di Kota Jambi. Kontribusi sektor perikanan terhadap sektor - sektor lainnya merupakan implikasi dari potensi perikanan yang ada di Kota Jambi dan diharapakan potensi tersebut juga dapat berdampak pada peran sektor perikanan dalam struktur ekonomi. Peran yang diharapkan pertama, melalui peningkatan pendapatan masyarakat perikanan. Kedua, peningkatan jumlah tenaga kerja yang terserap pada sektor perikanan yang pada akhirnya akan mengurangi jumlah pengangguran dan ketiga, mampu memanfaatkan penggunaan lahan yang sempit. Berdasarkan data perkembangan perdagangan serta produksi ikan hias di Kota Jambi dan peluang untuk peningkatan pertumbuhan Rumah Tangga Perikanan (RTP) sektor ikan hias serta peningktan pendapatan masyarakat perikanan, maka peneliti tertarik untuk mengetahui "Analisis usaha ikan hias air tawar di Kota Jambi".

\section{METODE PENELITIAN}

Penelitian ini akan dilaksanakan pada seluruh kecamatan di Kota Jambi, responden yang diambil dibatasi hanya pada pembudidaya yang menjalankan usahanya yang memelihara benih ikan hias dari larva sampai ukuran $3-5 \mathrm{~cm}$, dengan jenis ikan cupang, guppy dan botia. Untuk menggambarkan usaha ikan hias di Kota Jambi dilakukan metode 
pengamatan dan wawancara langsung terhadap pembudidaya ikan hias untuk mendapatkan gambaran usahatani ikan hias jenis cupang, guppy dan botia di lokasi penelitian, karakteristik petani dan proses usahatani dan budidaya ikan hias air tawar yang dilakukan pembudidaya di Kota Jambi. Sedangkan untuk melakukan analisa usaha ikan hias dilakukan dengan :

\section{Analisis Penerimaan dan Pendapatan Usaha ikan hias}

Analisis pendapatan dalam kegiatan usaha ini didukung oleh data dalam penerimaan usaha, kemudian dianalisis tingkat pendapatan yang diperoleh dengan mempertimbangkan besaran penerimaan dan biaya. Penerimaan usaha pada dasarnya merupakan perkalian antara produksi yang diperoleh dengan harga jual yang ada, secara matematik dapat dirumuskan sebagai berikut :

$$
\mathrm{TR}=\mathrm{Y} \times \mathrm{Py}
$$

Dimana: $\quad T R=$ Total Penerimaan $(\mathrm{Rp})$

$\mathrm{Y}=$ = Produksi yang diperoleh dalam suatu usaha (ekor).

Py = Harga yang diterima (Rp/ekor).

Setelah besarnya biaya dan penerimaan di analisis, maka dapat dilakukan analisis pendapatan yang diperoleh, dimana pendapatan usaha ikan hias merupakan selisih antara penerimaan dan biaya, dapat dirumuskan secara matematis yaitu :

$$
\mathrm{Pd}=\mathrm{TR}-\mathrm{TC}
$$

$$
\begin{aligned}
\text { Dimana : } & \mathrm{Pd}=\text { pendapatan usaha ikan hias (Rp.) } \\
& \mathrm{TR}=\text { total penerimaan (Rp.). } \\
\mathrm{TC} & =\text { total pengeluaran (Rp.). }
\end{aligned}
$$

Kriteria yang digunakan dalam analisis pendapatan ini adalah :

TR>TC : ushaa yang dijalankan memberikan keuntungan.

$\mathrm{TR}=\mathrm{TC}$ : usaha yang dijalankan impas (Break Event Point)

$\mathrm{TR}<\mathrm{TC}$ : ushaa yang dijalankan mengalami kerugian.

Analisis biaya usaha ikan hias pada jenis usaha berbeda dapat dilihat pada Tabel 4. Secara sistematis, perhitungan total biaya (total cost) merupakan penjumlahan dari biaya tetap (TFC) dan biaya variabel (TVC). Formula yang digunakan untuk menghitung pengeluaran total (Total Cost) adalah sebagai berikut :

$$
\mathrm{TC}=\mathrm{FC}+\mathrm{VC}
$$

$$
\begin{aligned}
\text { Dimana : } & \text { TC } \\
\text { FC } & =\text { Fotal Cost (biaya total). } \\
\text { VC } & =\text { Variable Cost (biaya tetap). }
\end{aligned}
$$

Untuk menghitung total biaya rata - rata (average total cost) adalah penjumlahan biaya tetap rata - rata (AFC) dengan biaya variabel rata - rata (AVC).

Rumus yang digunakan yaitu :

$$
A C=A F C+A V C
$$

$$
\text { Dimana : } \quad \begin{array}{ll}
\text { AC } & =\text { Average Cost (biaya rata }- \text { rata) } . \\
\text { AFC } & =\text { Average Fixed Cost (biaya tetap rata }- \text { rata). } \\
\text { AVC } & =\text { Average Variable Cost (biaya tidak tetap rata }- \text { rata). }
\end{array}
$$


Tabel 4. Struktur Biaya Rata- rata Usaha Ikan Hias Pada Skala Usaha Yang Berbeda.

\begin{tabular}{|c|c|c|c|}
\hline Uraian & $\begin{array}{c}\text { Usaha Ikan } \\
\text { Hias Skala } \\
\text { Kecil }\end{array}$ & $\begin{array}{l}\text { Usaha Ikan Hias } \\
\text { Skala Menengah }\end{array}$ & $\begin{array}{c}\text { Usaha Ikan } \\
\text { Hias Skala } \\
\text { Besar }\end{array}$ \\
\hline \multicolumn{4}{|l|}{ Biaya Investasi } \\
\hline - Lahan & V & V & V \\
\hline - Bangunan & V & V & V \\
\hline - Wadah & V & V & V \\
\hline pemeliharaan & V & V & V \\
\hline - Induk & V & V & V \\
\hline - Peralatan & V & V & V \\
\hline Total Biaya Investasi & Total V & Total V & Total V \\
\hline \multicolumn{4}{|l|}{ Biaya Tetap } \\
\hline - Listrik & $x$ & $x$ & $x$ \\
\hline - Penyusutan & $x$ & $x$ & $x$ \\
\hline - Pajak & $x$ & $x$ & $x$ \\
\hline - Tenaga Kerja & $x$ & $x$ & $x$ \\
\hline Total Biaya Tetap & Total X & Total X & Total X \\
\hline \multicolumn{4}{|l|}{ Biaya Variabel } \\
\hline - Pakan & Y & Y & Y \\
\hline - Pengemasan & Y & Y & Y \\
\hline - Obat-Obatan & Y & Y & Y \\
\hline Total Biaya Variabel & Total Y & Total Y & Total Y \\
\hline Total Biaya & $V+X+Y$ & $V+X+Y$ & $V+X+Y$ \\
\hline
\end{tabular}

\section{Analisis Imbangan Penerimaan dan Biaya $(R / C)$}

Analisis imbangan penerimaan dan biaya ( $R / C$ rasio) menunjukkan penerimaan yang diperoleh pembudidaya dari setiap rupiah pengeluaran yang dikeluarkan untuk usaha ikan hias sebagai manfaat. Analisis rasio ini dapat digunakan untuk mengukur tingkat keuntungan relatif terhadap kegiatan usaha sehingga dapat dijadikan penilaian terhadap keputusan petani untuk menjalankan usahatani tertentu. Formula yang digunakan adalah

$$
\mathrm{R} / \mathrm{C}=\frac{\text { Penerimaan } \text { Total }}{\text { Total Biaya }}=\frac{T R}{T C}
$$

Usahatani efisien apabila $R / C$ lebih besar dari 1 atau ( $R / C>1$ ) artinya untuk setiap $R p .1,00$ biaya yang dikeluarkan akan memberikan keuntungan lebih dari Rp.1,00. Sebaliknya jika $\mathrm{R} / \mathrm{C}$ lebih kecil dari atau $(\mathrm{R} / \mathrm{C}<1)$ maka dikatakan setiap Rp. 1,00 biaya yang dikeluarkan akan memberikan penerimaan lebih kecil dari Rp. 1,00 sehingga usahatani dinilai tidak efisien. Semakin tinggi nilai $R / C$, semakin menguntungkan usaha tersebut.

Net $B / C$ merupakan perbandingan antara NPV total dari benefit bersih terhadap total biaya bersih. Menurut Soekartawi (1995) dalam Zulpahmi (2015), analisis B/C Ratio pada prinsipnya hampir sama dengan analisis $R / C$ Ratio, hanya saja pada analisis $B / C$ Ratio ini 
data yang dipentingkan adalah besarnya manfaat. Sedangkan menurut Kadariah, $L$ et al, 1978 dalam Nugroho, S (2008). Net B/C digunakan untuk ukuran tentang efisiensi dalam penggunaan modal. Rumus perhitungannya adalah :

$$
\text { Net } \mathrm{B} / \mathrm{C}=\frac{\sum_{t}^{n} \frac{B t}{(1+i)^{t}}}{\sum_{t}^{n} \frac{C t}{(1+i)^{t}}}
$$

Keterangan: Bt = Benefit pada tahun ke $-\mathrm{t}$.

Ct = Biaya pada tahun ke-t.

$\mathrm{i} \quad=$ tingkat bunga yang berlaku .

$\mathrm{t}=$ jangka waktu proyek/usaha.

$\mathrm{n} \quad=$ umur proyek/usaha.

kriteria kelayakan pada metode ini adalah :

Net $B / C>1$, usaha dianggap layak, maanfaat yang diperoleh lebih besar dari biaya yang dikeluarkan, dan jika Net B/C $<1$, usaha tidak layak, maanfaat yang diperoleh tidak cukup untuk menutupi biaya yang dikeluarkan sehingga usaha tidak layak dan efisien untuk dilaksanakan.

\section{HASIL DAN PEMBAHASAN}

\section{Gambaran Umum dan karakteristik Responden Usaha Ikan Hias.}

Pembudidaya responden di daerah penelitian memiliki karakteristik yang berbeda beda seperti perbedaan umur, tingkat pendidikan, lama pengalaman berusaha Ikan hias, dan sifat usaha (utama/sampingan). Karakteristik responden akan membantu menggambarkan kondisi usaha ikan hias di Kota Jambi. Jumlah pembudidaya yang terpilih menjadi responden sebanyak 27 orang yang terdiri dari 9 orang pembudidaya ikan hias cupang, 9 orang pembudidaya ikan hias Guppy dan 9 orang pembudidaya ikan hias botia di Kota Jambi. 
Tabel 8. Karakteristik Responden Pembudidaya Ikan Hias di Kota Jambi Tahun 2017.

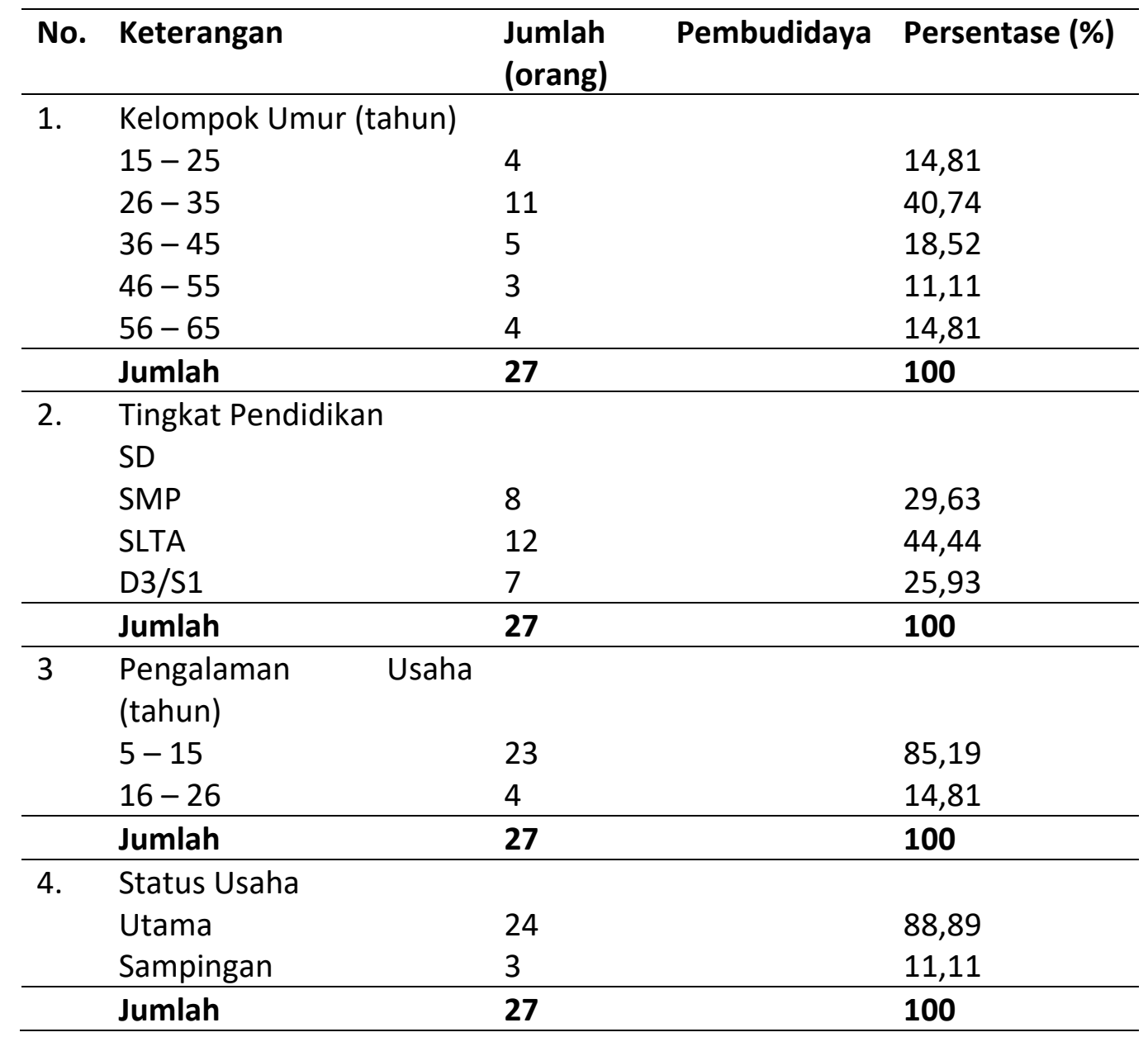

Faktor umur akan berpengaruh terhadap produktivitas kerja karena tenaga kerja manusia akan terus menurun seiring dengan bertambahnya usia. Oleh karena itu pembudidaya yang berumur relatif muda akan relatif dinamis dan mempunyai kemampuan fisik lebih kuat dan berani mengambil resiko. Karakteristik petani responden terlihat pada Tabel 8, dimana umur dari 27 pembudidaya ikan hias sebagai responden dikelompokkan menjadi pembudidaya responden berumur antara $15-25$ tahun sebanyak 4 orang (14,8 persen), 26-35 tahun sebanyak 11 orang (40,74 persen), 36-45 tahun sebanyak 5 orang (18,25 persen), $46-55$ tahun sebanyak 3 orang $(11,11$ persen) dan 56 - 65 tahun sebanyak 4 orang ( 14,81 persen). Jika berdasarkan umur produktif, maka terlihat bahwa sebaran umur responden sebagian besar merupakan petani dengan umur produktif. Selain itu dengan adanya persentase umur responden yang berumur lebih dari 50 tahun dapat diartikan pula bahwa untuk berusaha budidaya ikan hias dapat dilakukan oleh pembudidaya tanpa memandang faktor umur.

Pendidikan merupakan salah satu bentuk sumberdaya manusia yang terpenting. Tingkat pendidikan petani diukur melalui tingkat pendidikan formal yang pernah ditempuh diantaranya SD, SLTP, SLTA, dan D3/S1. Hasil yang diperoleh diketahui pendidikan yang ditempuh pembudidaya responden tingkat Sekolah Dasar sebanyak 0 
orang (0 persen), SLTP sebanyak 8 orang (29,63 persen), SLTA sebanyak 12 orang $(44,44$ persen) dan berpendidikan D3/S1 sebanyak 7 orang (25,93 persen). Berdasarkan hasil terlihat bahwa mayoritas petani mempunyai tingkat pendidikan sedang hingga tinggi (SLTA - D3/S1)).

Soekartawi (2002) menyatakan bahwa "Skala usaha akan mempengaruhi jumlah tenaga kerja yang dibutuhkan. Usaha pertanian skala kecil menggunakan tenaga kerja dalam keluarga dan tidak memerlukan tenaga kerja yang memilki keahlian. Sebaliknya pada usaha pertanian skala besar lebih banyak menggunakan tenaga kerja luar keluarga". Berdasarkan hasil penelitian luas wadah pemeliharaan belum berpengaruh besar terhadap hasil produksi pembudidaya selama satu tahun, ini dikarenakan luas tempat usaha tidak diikuti dengan pertambahan jumlah tenaga kerja yang memiliki keahlian. Seperti yang terlihat pada Tabel 9. Pada usaha ikan cupang hias skala kecil dengan luas wadah pemeliharaan sebesar $11,78 \mathrm{~m}^{2}$ mampu menghasilkan produksi sebesar 4.895 ekor, dibandingkan dengan usaha ikan cupang hias skala menengah dengan luas wadah pemeliharaan sebesar $12,42 \mathrm{~m}^{2}$ hanya mampu menghasilkan produksi sebesar 2.775 ekor dan usaha ikan cupang hias skala besar dengan luas wadah pemeliharaan sebesar 16,62 $\mathrm{m}^{2}$ mampu menghasilkan produksi dibawah dari skala usaha menengah dan kecil dengan produksi sebanyak 1.730 ekor.

Tabel. 9. Luas Wadah Pemeliharaan dan Produksi Usaha Ikan Hias Cupang, Guppy dan Botia.

\begin{tabular}{|c|c|c|c|c|c|c|c|c|c|}
\hline \multirow{3}{*}{$\begin{array}{l}\text { Jenis } \\
\text { Input }\end{array}$} & \multicolumn{9}{|c|}{ Skala Usaha Ikan Cupang Hias } \\
\hline & \multicolumn{3}{|c|}{ Kecil } & \multicolumn{3}{|c|}{ Menengah } & \multicolumn{3}{|c|}{ Besar } \\
\hline & Frisko & Dedy & $\begin{array}{l}\text { Dhan } \\
y\end{array}$ & $\begin{array}{l}\text { Said } \\
\text { Faisal } \\
\end{array}$ & Afandy & $\begin{array}{l}\text { Indraw } \\
\text { Lim }\end{array}$ & $\begin{array}{l}\text { M. } \\
\text { Fauzi }\end{array}$ & $\begin{array}{l}\text { Panu } \\
\mathbf{t}\end{array}$ & Zul Azmi \\
\hline $\begin{array}{l}\text { Luas } \\
\text { Wadah } \\
\left(\mathrm{m}^{2}\right)\end{array}$ & 7,62 & 11,78 & 11,10 & 13,35 & 15,30 & 12,42 & 20,03 & $\begin{array}{l}19,3 \\
8\end{array}$ & 16,62 \\
\hline \multirow[t]{2}{*}{$\begin{array}{l}\text { Produksi } \\
\text { (ekor) }\end{array}$} & 1.480 & 4.895 & 4.205 & 4.970 & 4.120 & 2.775 & 6.545 & $\begin{array}{l}3.45 \\
5\end{array}$ & 1.730 \\
\hline & \multicolumn{9}{|c|}{ Skala Usaha Ikan Guppy $\left(\mathrm{m}^{2}\right)$} \\
\hline \multirow{2}{*}{$\begin{array}{l}\text { Jenis } \\
\text { Input }\end{array}$} & \multicolumn{3}{|c|}{ Kecil } & \multicolumn{3}{|c|}{ Menengah } & \multicolumn{3}{|c|}{ Besar } \\
\hline & Felly & $\begin{array}{l}\text { Farha } \\
\mathrm{n}\end{array}$ & $\begin{array}{l}\text { Gunaw } \\
\text { an }\end{array}$ & $\begin{array}{l}\text { Crisnand } \\
\text { o }\end{array}$ & Sutar & Ian/Ida & $\begin{array}{l}\text { Ady } \\
\text { Junaidi }\end{array}$ & Rikky & Dekky \\
\hline \\
\hline $\begin{array}{l}\text { Wadah } \\
\left(\mathrm{m}^{2}\right)\end{array}$ & 1,8 & 1,8 & 3,94 & 6,75 & 7,63 & 9,88 & 39,5 & 14,2 & 10,83 \\
\hline \multirow[t]{2}{*}{$\begin{array}{l}\text { Produksi } \\
\text { (ekor) }\end{array}$} & 1.410 & 4.340 & 1.905 & 2.015 & 2.230 & 2.020 & 3.265 & 3.345 & 2.120 \\
\hline & \multicolumn{9}{|c|}{ Skala Usaha Ikan Botia $\left(\mathrm{m}^{2}\right)$} \\
\hline \multirow{2}{*}{$\begin{array}{l}\text { Jenis } \\
\text { Input }\end{array}$} & \multicolumn{3}{|c|}{ Kecil } & \multicolumn{3}{|c|}{ Menengah } & \multicolumn{3}{|c|}{ Besar } \\
\hline & Murni & Jihad & $\begin{array}{l}\text { Mardian } \\
\text { a }\end{array}$ & $\begin{array}{l}\text { Rasyid } \\
\text { Sy }\end{array}$ & $\begin{array}{l}\text { Nizamb } \\
\text { ik }\end{array}$ & Ibrahim & Anuar & Sobri & Hafazo \\
\hline $\begin{array}{l}\text { Luas } \\
\text { Wadah } \\
\left(\mathrm{m}^{2}\right)\end{array}$ & 6,0 & 6,0 & 2,9 & 7,02 & 10,0 & 10,5 & 10,5 & 34,0 & 16,3 \\
\hline $\begin{array}{l}\text { Produksi } \\
\text { (ekor) }\end{array}$ & 20.055 & $\begin{array}{l}13.30 \\
0\end{array}$ & 28.300 & 24.400 & 26.500 & 40.800 & 95.800 & 178.000 & 44.100 \\
\hline
\end{tabular}


Pada usaha ikan hias guppy skala usaha kecil yang di lakukan oleh responden dengan luas wadah pemeliharaan $1,8 \mathrm{~m}^{2}$ mampu memproduksi ikan guppy sebanyak 4.340 ekor sedangkan responden yang termasuk skala usaha besar dengan luas wadah pemeliharaan total $10,38 \mathrm{~m}^{2}$ hanya mampu memproduksi sebesar 2.120 ekor per tahun.

Sedangkan pada usaha ikan hias botia dengan skala usaha kecil responden memiliki luas wadah pemeliharaan 2,9 $\mathrm{m}^{2}$ mampu memproduksi sebanyak $28 . .300$ ekor dan responden pada skala usaha besar dengan luas wadah pemeliharaan $16,3 \mathrm{~m}^{2}$ hanya mampu memproduksi sebanyak 44.100 ekor.

Berdasarkan data diatas terjadi ketidak selarasan antara besaran luas lahan pemeliharaan dengan jumlah produksi yang dihasilkan oleh pembudidaya ikan cupang hias, hal ini dikarenakan tingkat pendidikan, umur dan pengalaman pelaku pembudidaya dalam menjalankan usaha ikan hias cupang yang berbeda dan segmen pasar yang dituju berbeda - beda, terutama pada skala usaha kecil yang lebih memilih perputaran usaha lebih cepat dengan mengejar jumlah produksi yang tinggi dan dapat langsung di jual kepasar tradisional, sedangkan pembudidaya dengan skala usaha menengah dan besar sudah lebih mengedepankan kualitas dan pengelolaan usaha dilakukan sendiri/langsung oleh pemilik usaha, sehingga tidak maksimal dalam memanfaatkan lahan yang dimiliki.

\section{Analisis Peneriamaan dan Pendapatan Usaha Ikan Hias.}

Tabel. 10. Analisa Usaha Ikan Hias Air Tawar Kota Jambi.

\begin{tabular}{lcccccc}
\hline $\begin{array}{l}\text { Skala Usaha ikan } \\
\text { hias Cupang }\end{array}$ & $\begin{array}{c}\text { Rata -Rata } \\
\text { Penerimaan }\end{array}$ & $\begin{array}{c}\text { Rata - rata } \\
\text { Total Biaya }\end{array}$ & $\begin{array}{c}\text { Rata - rata } \\
\text { Pendapatan }\end{array}$ & $\begin{array}{c}\text { Rata - } \\
\text { rata R/C }\end{array}$ & $\begin{array}{c}\text { Rata - rata } \\
\text { NPV }\end{array}$ & $\begin{array}{c}\text { Rata - rata } \\
\text { Net B/C }\end{array}$ \\
\hline Kecil & $75,735,743$ & $35,155,800$ & $40,579,943$ & 2.15 & $36,232,092.26$ & 1.15 \\
\hline Menengah & $110,531,780$ & $42,497,200$ & $68,034,580$ & 2.60 & $60,745,160.71$ & 1.60 \\
\hline Besar & $79,925,703$ & $42,152,800$ & $37,772,903$ & 1.90 & $33,725,806.55$ & 0.90 \\
\hline Skala Usaha Ikan & Rata -Rata & Rata - rata & Rata - rata & Rata - & Rata - rata & Rata - rata \\
Hias Guppy & Penerimaan & Total Biaya & Pendapatan & rata R/C & NPV & Net B/C \\
\hline Kecil & $41,681,782$ & $20,626,476$ & $21,055,305$ & 2.02 & $18,799,379.89$ & 1.02 \\
\hline Menengah & $37,054,732$ & $27,801,667$ & $9,253,065$ & 1.33 & $8,261,665.18$ & 0.33 \\
\hline Besar & $101,976,040$ & $66,824,767$ & $35,151,273$ & 1.53 & $31,385,065.48$ & 0.53 \\
\hline Skala Usaha Ikan & Rata -Rata & Rata - rata & Rata - rata & Rata - & Rata - rata & Rata - rata \\
Hias Botia & Penerimaan & Total Biaya & Pendapatan & rata R/C & NPV & Net B/C \\
\hline Kecil & $30,801,810$ & $23,497,833$ & $7,303,977$ & 1.31 & $6,521,408.11$ & 0.31 \\
\hline Menengah & $45,811,792$ & $22,961,233$ & $22,850,558$ & 2.00 & $20,402,284.23$ & 1.00 \\
\hline Besar & $158,817,542$ & $71,419,300$ & $87,398,242$ & 2.22 & $78,034,144.35$ & 1.22 \\
\hline Penerimaan
\end{tabular}

Penerimaan.

Berdasarkan data produksi tahun 2017, pada usaha budidaya ikan hias cupang skala kecil peneriman tertinggi sebesar $\mathrm{Rp}$. 86.054.000,- dengan rata - rata penerimaan $\mathrm{Rp}$. 69.482.333,- skala menengah peneriman tertinggi sebesar Rp. 111.268.000,- dengan rata - rata penerimaan Rp. 93.572.000,- dan skala besar peneriman tertinggi sebesar Rp. 94.744.000,- dengan rata - rata penerimaan Rp. 73.326.333,-. Pada usaha budidaya ikan hias guppy skala usaha kecil total penerimaan tertinggi sebesar Rp. 36.043.000,- dengan rata - rata penerimaan Rp. 38.240.167,- skala menengah peneriman tertinggi sebesar Rp. 38.785.000,- dengan rata - rata penerimaan Rp. 33.995.167,- dan skala besar peneriman tertinggi sebesar Rp. 120.830 .000 ,- dengan rata - rata penerimaan Rp. 93.556.000,-. Sedangkan usaha budidaya ikan hias botia skala usaha kecil total penerimaan tertinggi sebesar Rp. 38.912.500,- dengan rata - rata penerimaan Rp. 
28.258.542,-, skala menengah peneriman tertinggi sebesar Rp. 56.100.000,- dengan rata - rata penerimaan Rp. 42.029.167,- dan skala besar peneriman tertinggi sebesar Rp. 244.750.000,- dengan rata - rata penerimaan Rp. 145.704.167,-.

\section{Biaya}

Untuk usahabudidaya ikan hias cupang total biaya cukup bervariasi, untuk skala kecil total biaya tertinggi Rp. 64.651.000,- dan terendah Rp. 40.774.000,- dengan biaya rata rata Rp. 53.144.000,-, skala menengah total biaya tertinggi Rp. 63.444.000,- dan terendah Rp. 55.191.000,- dengan biaya rata - rata Rp. 59.646.000, dan skala besar total biaya tertinggi Rp. 74.688.000,- dan terendah Rp. 50.504.000,- dengan biaya rata - rata Rp. 61.525.333,-. Pada usaha budidaya ikan hias guppy total biaya untuk skala kecil yang tertinggi Rp. 38.424.000,- dan terendah Rp. 32.564.000,- dengan biaya rata - rata Rp. 34.884.000,-, skala menengah total biaya tertinggi Rp. 40.591..000,- dan terendah Rp. 37.521.000,- dengan biaya rata - rata Rp. 39.874.333, dan skala besar total biaya tertinggi Rp. 117.965.000,- dan terendah Rp. 67.983.000,- dengan biaya rata - rata Rp. 99.658.333,-, sedangkan pada usaha budidaya ikan hias Botia total biaya untuk skala kecil yang tertinggi Rp. 31.465.600,- dan terendah Rp. 24.475.600,- dengan biaya rata - rata Rp. 26.924.333,-, skala menengah total biaya tertinggi Rp. 31.373.600,- dan terendah Rp. 26.423.400,- dengan biaya rata - rata Rp. 28.233.733, dan skala besar total biaya tertinggi Rp. 198.276.600,- dan terendah Rp. 62.656.400,- dengan biaya rata - rata Rp. 123.875.133,-.

Untuk biaya investasi yang komponen yang sangat mempengaruhi besarnya investasi adalah biaya pembuatan bangunan atau pembelian/sewa lahan, pembuatan wadah pemeliharaan ikan hias dan pembelian indukan ikan hias. Sedangkan untuk biaya operasional yang terdiri dari biaya tetap dan biaya variabel, pada usaha budidaya ikan hias cupang jenis biaya tetap yang dikeluarkan adalah alat tulis kantor, biaya pemeliharaan, listrik, telpon, air, BBM, pajak motor, Pajak, Gaji karyawan/tenaga kerja dan biaya pakan indukan. Untuk biaya operasional usaha budidaya ikan hias guppy komponen biaya tetap dan biaya variabel yang digunakan hampir sama dengan komponen biaya pada usaha budidaya ikan hias cupang. Sedangkan biaya operasional pada usaha budidaya ikan hias Botia jenis biaya tetap yang dikeluarkan secara umum hampir sama dengan usaha budidaya ikan hias cupang dan guppy, yang membedakan adalah pada usaha budidaya ikan hias botia tidak terdapat komponen biaya tetap untuk pakan perawatan induk, dan di ganti dengan biaya pembelian larva ikan botia.

\section{Pendapatan}

Analisa pendapatan dilakukan untuk melihat seberapa kemampuan suatu usaha untuk memberikan keuntungan bagi investor. Analisa pendapatan di peroleh melalui penjumlahan seluruh penerimaan, artinya dalam usaha budidaya ikan hias, penerimaan adalah total produksi ikan hias yang dihasilkan oleh pembudidaya selama 1 periode atau tahun dikalikan dengan harga jual yang di terima oleh pembudidaya, lalu dikurangi dengan total pengeluaran atau total biaya. Dari tabel 10 dapat terlihat bahwa pendapatan usaha budidaya ikan hias cupang dengan skala menengah atas nama Said Faisal memberikan pendapatan yang tertinggi sebesar Rp. 47.824.000,- selama tahun 2017, selanjutnya di ikuti oleh usaha budidaya ikan hias botia dengan responden atas 
nama Sobri, dengan pendapatan Rp. 46.473.400,-. Hal ini dipengaruhi oleh berbagai faktor, diantaranya : 1). Kemampuan/keahlian pembudidaya ikan hias dalam merawat benih ikan hias hingga siap jual, 2). Kejelian dalam melihat peluang pasar dari sisi waktu penjualan sehingga memperoleh harga yang maksimal, 3). Kemampuan dalam memaksimalkan pemanfaatan lahan/wadah pemeliharaan yang dimiliki sehingga mampu memaksimalkan jumlah produksi ikan hias.

Dari kedua jenis usaha budidaya ini. Menurut penulis, usaha budidaya ikan hias botia memiliki resiko yang cukup tinggi. Pertama, hal ini dikarenakan ikan hias ini belum dapat di produksi secara perkawinan antara induk jantan dan betina secara luas, sehingga ada ketergantungan pembudidaya dalam mendapatkan larva untuk di budidayakan pada kondisi alam dan lingkungan. Kendala kedua pada usaha budidaya botia, memiliki tingkat kesulitan dalam perawatan yang cukup tinggi, dikarenakan pembudidaya harus memiliki keahlian dan ketekunan dalam merawat larva ikan agar terhindar dari penyakit hingga siap dijual, dikarenakan pembudidaya harus membuat larva ikan hias botia mampu beradaptasi dengan kondisi air yang telah disiapkan oleh pembudidaya. Sebaliknya untuk ikan hias cupang, untuk memperoleh larva cukup mudah, karena telah dapat dilakukan proses pekawinan antara induk jantan dan betina, dan untuk memperoleh indukan tidak terlalu sulit serta harga yang cukup terjangkau, terkecuali induk yang meiliki kualitas baik. Sedangkan usaha budidaya ikan hias guppy belum memberikan nilai pendapatan yang cukup menjanjikan pada tahun pertama usaha.

\section{Analisis Imbangan Penerimaan dan Biaya}

Berdasarkan hasil analisis rata - rata nilai $\mathrm{R} / \mathrm{C}$ ratio penerimaan total terhadap biaya total di masing - masing usaha budidaya ikan hias cupang diperoleh sebesar 1,19-1,31, untuk usaha budidaya ikan hias guppy sebesar 0,94-1,10 dan untuk usaha budidaya ikan hias botia sebesar 1,05-1,18. Nilai tersebut berarti setiap Rp 1,- biaya yang dikeluarkan untuk usaha ikan hias cupang memperoleh penerimaan sebesar Rp 1,19,-- Rp. 1,31,-, usaha ikan hias guppy memperoleh penerimaan tertinggi sebesar Rp. 0,94 - 1,10,- dan usaha ikan hias botia memperoleh penerimaan tertinggi sebesar Rp. 1,05 - 1,18,-Berdasarkan uraian tersebut kondisi usaha pada tiap pembudidaya ikan hias cupang berada pada keadaan perusahaan yang efisien, karena penerimaan total yang diperoleh lebih besar dari biaya total yang dikeluarkan. Sedangkan usaha budidaya ikan hias guppy, hanya pada skala usaha kecil yang keseluruhan respondennya memiliki rata -rata tingkat $\mathrm{R} / \mathrm{C}$ ratio diatas 1 dan pada ikan hias botia $\mathrm{R} / \mathrm{C}$ ratio tertinggi terdapat pada skala usaha menengah. Usaha budidaya ikan hias botia lebih efisien karena memiliki nilai R/C lebih besar diikuti usaha ikan hias cupang dan guppy, Hal ini disebabkan oleh, usaha budidaya ikan hias botia hanya pada skala usaha menengah yang keseluruhan respondennya memiliki tingkat $\mathrm{R} / \mathrm{C}$ ratio diatas 1 . Berdasarkan uraian tersebut kondisi tiap usaha tidak semuanya berada pada keadaan perusahaan yang memperoleh laba, karena masih didapati penerimaan yang diperoleh lebih kecil dari biaya produksi yang dikeluarkan.

\section{Analisa Net Benefit Cost Ratio (Net B/C)}

Nilai rata - rata B/C Ratio pada usaha budidaya ikan hias cupang pada tiga skala usaha yakni 1,15 skala kecil, 1,60 skala menengah, 0,90 skala besar. Nilai B/C Ratio tertinggi di peroleh dari usaha budidaya ikan hias jenis cupang pada skala menengah dengan dilai 
1,60 , artinya setiap satu rupiah yang dikeluarkan oleh pembudidaya akan diperoleh keuntungan sebesar 1,60 rupiah atau setiap Rp. 1.000,- biaya yang dikeluarkan oleh pembudidaya akan memperoleh keuntungan Rp. 1.600,- hal ini juga disebabkan oleh rata - rata total nilai penerimaan yang diterima pada skala usaha menengah hampir lebih besar dari skala usaha besar.

Pada usaha budidaya ikan hias guppy nilai rata - rata B/C ratio yang diperoleh adalah sebesar 1,02 untuk skala kecil, 0,33 untuk skala menengah dan 0,53 untuk skala usaha besar. Artinya dari analisis B/C Ratio untuk usaha budidaya ikan hias guppy, skala usaha yang lebih layak untuk dijalankan adalah usaha budidaya ikan hias guppy pada skala kecil. Dan nilai ini tergolong cukup kecil. Karena dari setiap satu rupiah yang dikeluarkan oleh pembudidaya akan diperoleh keuntungan sebesar 1,02 rupiah atau setiap Rp. 1.000,biaya yang dikeluarkan oleh pembudidaya akan memperoleh keuntungan Rp. 1.020,-Pada usaha budidaya ikan hias guppy, total rata - rata biaya hampir sama dengan total rata - rata penerimaan.

Selanjutnya untuk usaha budidaya ikan hias botia memiliki nilai rata - rata Net B/C 0,31 untuk skala usaha kecil, untuk skala usaha menengah dan besar masing masing memiliki rata - rata net $\mathrm{B} / \mathrm{C} 1,00$ dan 1,22 . Hasil analisis $\mathrm{B} / \mathrm{C}$ ratio pada ikan hias botia menunjukkan bahwa Skala usaha besar memperoleh nilai paling tinggi, yakni sebesar 1,22 Artinya dalam setiap satu rupiah yang dikeluarkan sebagai biaya akan menghasilkan manfaat bersih sebesar nilai sebesar Rp. 1,22, atau setiap Rp. 1000,- biaya yang dikeluarkan akan memperoleh keuntungan sebesar Rp. 1.220,--

\section{KESIMPULAN}

Secara keseluruhan gambaran umum usaha budidaya ikan hias di Kota Jambi masih dilakukan dengan cara konvensional dan semi konvensional, dimulai dari proses awal penanganan larva, perawatan benih hingga pemanenan. Tingkat pendapatan diperoleh rata - rata tertinggi untuk usaha ikan hias cupang pada skala menengah sebesar Rp. 33.926.000,- per tahun, usaha ikan hias guppy pada skala kecil sebesar Rp. 3.356.167,-- per tahun dan usaha ikan hias botia pada skala besar sebesar Rp. 21.829.033,- per tahun. Berdasarkan hasil analisis rata - rata $\mathrm{R} / \mathrm{C}$ ratio penerimaan total terhadap biaya total nilai tertinggi di masing-masing usaha ikan hias cupang diperoleh sebesar 2,60, usaha budidaya ikan hias guppy sebesar 1,02 dan usaha ikan hias botia sebesar 1,22. Nilai tersebut berarti setiap tambahan Rp 100 biaya yang dikeluarkan untuk usaha ikan hias cupang memperoleh tambahan penerimaan sebesar Rp 260,-, usaha ikan hias guppy memperoleh tambahan penerimaan sebesar Rp. 102,- dan usaha ikan hias botia memperoleh tambahan penerimaan sebesar Rp. 122. Rata - rata Net Present Value tertinggi pada usaha budidaya ikan hias cupang skala menengah sebesar Rp 60.745.160,71, usaha budidaya ikan hias guppy pada skala usaha besar sebesar Rp. 31.385.065,48, usaha budidaya ikan hias botia yang larvanya bersumber dari tangkapan alam, nilai rata -rata NPV tertinggi terdapat pada skala usaha besar dengan nilai Rp. 78.034.144,35. Secara keseluruhan usaha budidaya ikan hias ini dikatakan layak untuk dijalankan apabila memiliki nilai NPV $>0$. Sedangkan berdasarkan hasil perhitungan Net B/C, usaha ikan hias di Kota Jambi yang layak untuk dijalankan dan dapat dikembangkan adalah Usaha ikan 
hias cupang dengan skala usaha kecil dengan nilai rata - rata B/C Ratio 1,15 dan menengah dengan nilai rata - rata $B / C$ Ratio 1,60 , Usaha ikan hias guppy dengan skala usaha kecil dengan nilai rata - rata $B / C$ Ratio 1,02 dan Usaha ikan hias botia dengan skala usaha menengah dengan nilai rata - rata $\mathrm{B} / \mathrm{C}$ Ratio 1,00 dan besar dengan nilai rata - rata B/C Ratio 1,22.

Untuk meningkatkan produksi dan pendapatan pembudidaya ikan hias di Kota Jambi, perlu dilakukan pembinaan secara intensif agar dapat memperbaiki pengelolaan budidaya ikan hias, dengan cara memperbaiki kualitas induk, meningkatkan kapasitas/keahlian sumberdaya manusia dan peningkatan sarana pemeliharaan agar dapat meningkatkan kualitas dan kuantitas ikan hias. Serta, meningkatkan peran aktif Pemerintah, terutama penyuluh dalam membimbing para pembudidaya ikan hias dalam menjalankan usaha budidaya ikan hias yang akan sangat membantu dalam upaya meningkatkan produksi dan pendapatan pembudidaya ikan hias di Kota Jambi, dan membuka peluang pasar ikan hias internasional.

\section{DAFTAR PUSTAKA}

Badan Pusat Statistik Kota Jambi, 2015. Kota Jambi Dalam Angka 2015. Jambi.

Dinas Pertanian dan Ketahanan Pangan Kota Jambi, 2017. Laporan Tahunan Bidang Perikanan 2016. Jambi.

Dinas Pertanian Peternakan Perikanan dan Kehutanan Kota Jambi, 2016. Laporan

Statistik Perikanan Budidaya Bidang Perikanan 2015. Jambi Dalam Angka 2015. Suratiyah, Ken. 2008. IImu Usahatani. Penebar swadaya. Jakarta

Soekartawi. 2002. Teori Ekonomi Produksi dengan Pokok Bahasan Analisis Fungsi CobbDouglas, Cetakan Ke 3. Rajawali Press: Jakarta.

Zulpahmi. R, 2015. Analisis Usahatani Padi Sawah Sistem Ratun Pada Lahan Pasang Surut Di Kecamatan Berbak Kabupaten Tanjung Jabung Timur [Tesis]. Jambi (ID). Universitas Jambi. 